\title{
Game Hafalan Ayat Al-Qur'an Berbasis Android Bagi Siswa Sekolah Dasar Islam Terpadu
}

\author{
Syafrul Irawadi ${ }^{1}$, Maxrizal $^{2}$, Sujono $^{3}$ \\ Institut Sains dan Bisnis Atma Luhur \\ e-mail: ${ }^{1}$ syafrul@atmaluhur.ac.id, ${ }^{2}$ maxrizal@atmaluhur.ac.id, ${ }^{3}$ sujono@atmaluhur.ac.id \\ Diajukan: 30 April 2020; Direvisi: 23 Juni 2020; Diterima: 21 Juli 2020
}

\begin{abstract}
Abstrak
Pendidikan karakter semenjak usia dini merupakan program yang sedang digalakkan oleh pemerintah. Untuk menjawab tantangan itu, SD IT Al Mansyur yang terdapat di Desa Balunijuk, Kabupaten Bangka, menyelenggarakan pendidikan formal yang berbasis ilmu pengetahuan, iman dan takwa. Proses pembelajaran di SD IT Al Mansyur masih bersifat klasikal. Kesulitan yang sering ditemui siswa adalah sulitnya siswa menghafal ayat-ayat Al-Qur'an karena suasana pembelajaran yang terkesan formal dalam bentuk hafalan. Untuk itu, pada penelitian ini dikembangkan game berbasis Android untuk mempermudah hafalan ayat Al-Qur'an bagi siswa. Game hafalan dirancang dan dibangun menggunakan metode Waterfall dan menggunakan Uniform Resource Locator (URL) untuk mengambil data suara ke Dropbox service. Penelitian ini menghasilkan game hafalan yang telah memiliki fitur-fitur hafalan untuk menghafal Al-Qur'an di SD IT Al Mansyur.
\end{abstract}

Kata kunci: Game Hafalan Al-Qur'an, Android, Teknologi Informasi, Aplikasi Game.

\begin{abstract}
Character education since an early age is a program that is being promoted by the government. To answer that challenge, SD IT Al Mansyur located in Balunijuk Village, Bangka Regency, organizes formal education based on science, faith, and piety. The learning process at Al Mansyur Elementary School IT is still using a traditional. The difficulty that is often encountered by students is the difficulty of students memorizing verses of the Quran because of the learning atmosphere that seems formal in the form of memorization. For this reason, this research developed an Android-based game to facilitate memorization of Quran verses for students. Rote games are designed and built using the waterfall method and use a Uniform Resource Locator (URL) to retrieve voice data to the Dropbox service. This research produced a memorization game that already has memorization features to memorize the Quran at SD IT Al Mansyur.
\end{abstract}

Keywords: Quran Recitation Games, Android, Information Technology, Game Applications.

\section{Pendahuluan}

Sekolah Islam Terpadu merupakan salah satu lembaga pendidikan yang mengembangkan pembelajaran berbasis ilmu pengetahuan teknologi (Iptek) dan iman takwa (Imtak) bagi peserta didiknya. Sekolah Dasar Islam Terpadu (SD IT) merupakan tingkatan dasar atau jenjang awal yang menerapkan keseimbangan antara Iptek dan Imtak. SD IT berfokus pada pengembangan pengetahuan seperti yang dikembangkan oleh kurikulum yang ada di SD pada umumnya dan melengkapinya dengan pembelajaran akhlak dan Al-Qur'an secara intensif sebagai tambahan, yang belum banyak diterapkan di jenjang SD. Hal ini sejalan dengan program yang digalakkan pemerintah yaitu "pendidikan karakter" dari semenjak usia dini. Mengingat beban tambahan untuk pendidikan karakter melalui pendidikan akhlak dan Al-Qur'an, SD IT harus mampu mengembangkan kurikulum yang interaktif, menarik, dan mudah dipahami.

Salah satu SD IT yang ada di provinsi Kepulauan Bangka Belitung adalah SD IT Al Mansyur yang terdapat di Desa Balunijuk, Kabupaten Bangka. Lembaga yang memiliki slogan "SD IT Al Mansyur: Pencetak Para Penghafal Al-Qur'an" ini memiliki kurikulum dengan tujuan akhir selain lulusannya memiliki ijazah SD, lulusannya juga merupakan para penghafal Al-Qur'an. Penerapan kurikulum yang menarik dan mudah menghafal Al-Qur'an adalah tantangan berat untuk lembaga pendidikan ini. Pada kenyataannya, proses pembelajaran di SD IT Al Mansyur masih bersifat klasikal, seperti guru berceramah di depan kelas dan pembelajaran di lapangan (ke alam bebas di sekitar sekolah) dalam rangka pembelajaran untuk memperoleh pengetahuan dan penghafalan bacaan Al-Qur'an. Siswa dibebani dengan hafalan- 
hafalan harian. Hal ini kadang membuat para siswa jenuh dalam proses menghafal. Apalagi, tingkat kecerdasan siswa yang ada tidak merata, sehingga proses hafalan tiap siswa akan berbeda. Kesulitan yang sering ditemui siswa adalah sulitnya siswa menghafal ayat-ayat Al-Qur'an karena suasana pembelajaran yang terkesan formal dalam bentuk hafalan. Selain itu, siswa dengan sifat kekanak-kanakannya kadang akan sulit untuk dibebani hafalan ayat, karena karakter tanggung jawabnya belum terbentuk dengan sempurna.

Lembaga pendidikan ini belum menerapkan teknologi informasi dalam pembelajaran untuk menambah pengetahuan umum atau pun untuk mempermudah penghafalan bacaan Al-Qur'an. Para pengajar merupakan lulusan pesantren dan beberapa lulusan (alumni) Universitas Bangka Belitung, yang notabenenya tidak pada kompetensinya dalam mengajarkan teknologi informasi. Untuk itu, pada penelitian ini akan dikembangkan game hafalan ayat Al-Qur'an untuk mempermudah hafalan Al-Qur'an bagi siswa SD IT Al Mansyur.

Penelitian ini mengadopsi penelitian yang sejenis tentang pembuatan game Al-Qur'an berbasis Android telah banyak dikembangkan di antaranya adalah:

1. Penelitian yang dilakukan oleh Nurul Hidayah dan Royana Afwari dengan metode At-Taisir dari metode manual dijadikan Andoid, dengan metode Android tersebut bisa mempermudah penghafalan Al-Qur'an 85,9 persen [1].

2. Penelitian yang di lakukan oleh Vadlya Maarif, Hidayat Muhammad Nur, dan Wati Rahayu dengan membuat Aplikasi ilmu tajwid berbasis Android yang memuat materi ilmu tajwid disertai contoh pelafalan hukum yang memungkinkan sehingga pengguna mudah melihat contoh dan mendengar dari aplikasi yang digunakan sehingga mempermudah bagi umat Islam baik anak-anak, remaja maupun orang tua yang mempunyai keterbatasan waktu untuk belajar dengan mudah dan dapat digunakan kapan saja [2].

3. Penelitian yang dilakukan oleh Fitriana Firdausi dengan mempertimbangkan optimasi kecerdasan majemuk para siswa, maka penelitian ini dilakukan untuk lebih mempermudah dan memotivasi siswa dalam menghafal Al-Qur'an [3].

\section{Kajian Pustaka}

\subsection{Dropbox}

Game hafalan menggunakan Uniform Resource Locator (URL) dalam pengambilan data suara animasi dan gambar ke Dropbox Service dengan layanan penyedia data berbasis web. Dropbox menggunakan sistem penyimpanan berjaringan yang memungkinkan pengguna untuk menyimpan dan berbagi data serta berkas dengan pengguna lain di internet dalam menggunakan sinkronisasi data. Hal ini adalah cara termudah untuk membuat cadangan dan sinkronisasi file antar komputer. Dropbox terbagi dalam 3 kategori, yaitu:

- $\quad$ Dropbox Desktop Application adalah perangkat lunak yang digunakan untuk melihat folder pada komputer desktop dan sinkronisasi perubahan ke web untuk komputer yang lainnya.

- Dropbox Website menyediakan akses file di komputer mana pun dari web browser dan juga dapat digunakan untuk berbagi file atau folder dengan orang lain.

- Dropbox Mobile Website dan Dropbox for Mobile Device menyediakan koneksi ke Dropbox dari pocket, sehingga dapat mengambil file yang dibutuhkan ke mana pun pergi.

Dropbox didirikan pada tahun 2007 oleh lulusan Massachusetts Institute of Technology (MIT)

Drew Houston dan Arash Ferdowsi. Dropbox merupakan Public Cloud Service dengan kategori SaaS (Storage as a Service), yang mempunyai karakteristik sebagai aplikasi atau layanan informasi tanpa berbayar untuk meng-install perangkat lunak serta infrastruktur sendiri, fokus pada konsumsi. Fungsinya sebagai arsip, backup, email, office, payroll atau expense, file atau data storage, photo atau layanan berbagi informasi, dan sebagainya [4].

\subsection{Android}

Android adalah sistem operasi untuk telepon seluler yang berbasis Linux. Android menyediakan platform terbuka bagi para pengembang buat menciptakan aplikasi mereka sendiri untuk digunakan oleh bermacam peranti bergerak. Awalnya, Google Inc. membeli Android Inc., pendatang baru yang membuat peranti lunak untuk ponsel. Kemudian untuk mengembangkan Android, dibentuklah Open Handset Alliance, konsorsium dari 34 perusahaan peranti keras, peranti lunak, dan telekomunikasi, termasuk Google, HTC, Intel, Motorola, Qualcomm, T-Mobile, dan Nvidia. Android Software Development Kit (Android SDK). Android SDK merupakan sebuah tools yang diperlukan untuk mengembangkan aplikasi berbasis Android menggunakan bahasa pemrograman Java. Pada saat ini Android SDK telah menjadi alat bantu dan Application Programming Interface (API) untuk mengembangkan aplikasi berbasis Android. 


\subsection{Unified Modelling Language (UML)}

UML dalam sebuah bahasa untuk menentukan visualisasi, konstruksi, dan mendokumentasikan artifacts dari sistem software, untuk memodelkan bisnis, dan sistem non-software lainnya. UML merupakan sistem arsitektur yang bekerja dalam OOAD dengan satu bahasa yang konsisten untuk menentukan, visualisasi, konstruksi, dan mendokumentasikan artifact yang terdapat dalam sistem. Artifact adalah sepotong informasi yang digunakan atau dihasilkan dalam suatu proses rekayasa software. Artifact dapat berupa model, deskripsi, atau software. Penelitian ini dimulai dengan interview kebutuhan aplikasi, dilakukan untuk mengetahui kebutuhan pembelajaran di SD IT Al Mansyur. Tahap analisis data dan kesesuaian kebutuhan, pengumpulan data dilakukan dengan cara studi lapangan dan studi pustaka. Selanjutnya, penelitian dilanjutkan pada tahap perancangan aplikasi yang dimulai dengan melakukan penyusunan ayat-ayat ke dalam konten. Selanjutnya, peneliti melakukan pengodean aplikasi. Setelah desain konten ditetapkan maka dilakukan implementasi pada tahap akhir, proses analisis ini berguna untuk memberikan bentuk alternatif yang diajukan sebagai satu teknik pemecahan masalah.

\section{Metode Penelitian}

Metode pengembangan yang digunakan untuk merancang dan membangun aplikasi game hafalan Al-Qur'an berbasis Android adalah metode Waterfall. Adapun langkah-langkah pengembangan sistem digambarkan dalam model berikut:

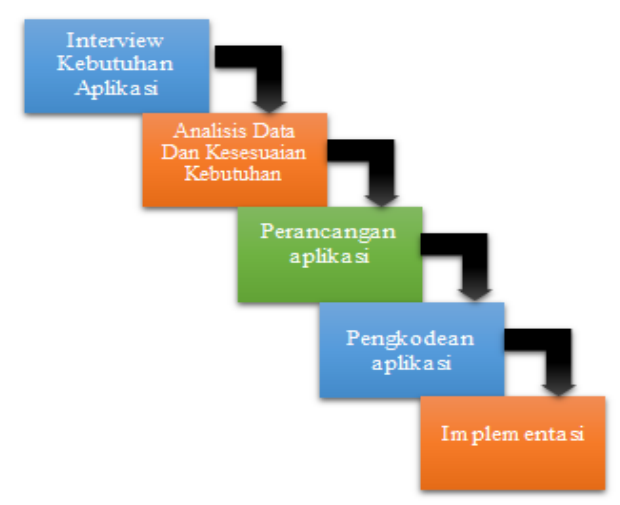

Gambar 1. Metode Waterfall menurut Pressman [5].

\subsection{Interview Kebutuhan Aplikasi}

Tahapan awal dalam membangun pembuatan game hafalan Al-Qur'an berbasis Android ini adalah interview kebutuhan dengan mengadakan wawancara calon pengguna. Di mana dalam metode ini merupakan proses interaktif yang melibatkan hubungan kerja yang dekat antara perancang dan calon pengguna dalam menganalisis, perencanaan model secara cepat dan tepat. Tahap pertama ini dilakukan peneliti melalui dua hal yaitu wawancara dan mengumpulkan library Al-Qur'an. Wawancara dilakukan untuk mengetahui seperti apa minat siswa terhadap jika disajikan dalam bentuk aplikasi Android.

\subsection{Analisis Data Dan Kesesuaian Kebutuhan}

Pada tahap ini, perencanaan model dilakukan setelah analisis dan interview kebutuhan aplikasi telah terpenuhi. Kemudian perancangan dilakukan sesuai dengan data yang telah didapatkan.

\subsection{Perancangan Aplikasi}

Pembangunan aplikasi Game Hafalan Al-Qur'an menggunakan Android Studio versi 3.3.0 dan SDK 28. Tahap perancangan ini merupakan tahapan penggambaran aplikasi yang akan dibangun. Rancangan perangkat lunak yang dibuat bersifat user friendly agar pengguna merasa nyaman dan mudah untuk menggunakannya.

\subsection{Pengodean Aplikasi}

Tahapan selanjutnya adalah proses rancangan sistem yang sudah dilakukan ke dalam bentuk bahasa pemrograman (coding). Pada pembuatan aplikasi ini, penulis menggunakan bahasa pemrograman Java dengan tools Android Studio. 


\subsection{Implementasi}

Tahapan implementasi di mana aplikasi game hafalan Al-Qur'an yang sudah sesuai dengan hasil perancangan arsitektur perangkat lunak, maka dapat diimplementasikan kepada siswa sebagai uji coba aplikasi untuk mengukur tingkat penggunaannya.

\section{Hasil dan Pembahasan}

Penelitian ini menghasilkan game hafalan ayat Al-Qur'an untuk mempermudah proses hafalan siswa Sekolah Dasar Islam Terpadu. Berikut ini activity diagram dan implementasi tampilan yang menggambarkan berbagai alur aktivitas dalam sistem yang sedang dirancang, bagaimana masing-masing alur berawal, decision yang mungkin terjadi, dan bagaimana mereka berakhir.

\subsection{Entity Relationship Diagram (ERD)} di bawah ini:

Dari hasil analisis data yang didapat, menghasilkan rancangan struktur basis data seperti gambar

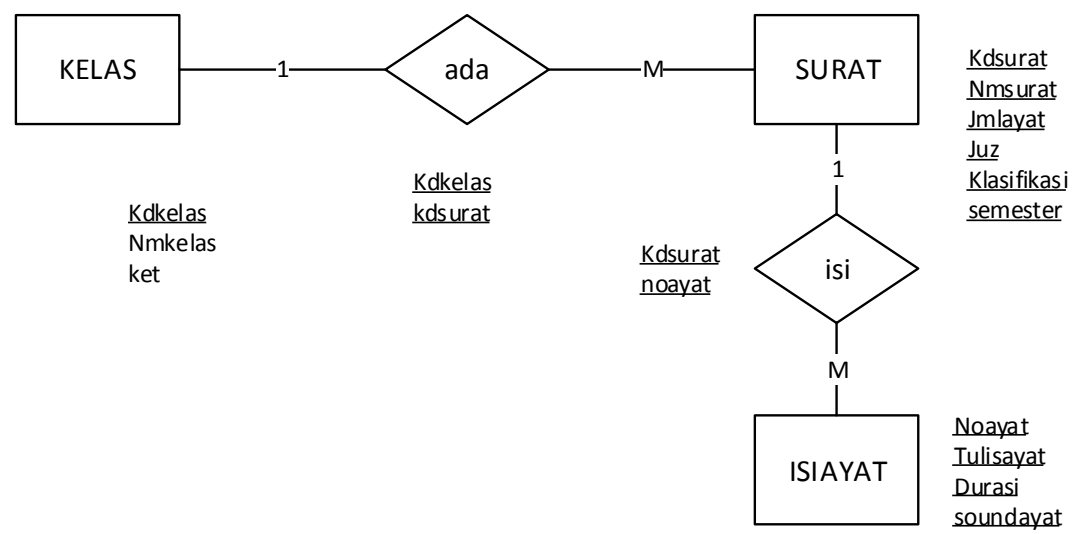

Gambar 2. Rancangan basis data.

\subsection{Activity Diagram Tampilan Depan}

Hasil tampilan aplikasi pada menu utama game hafalan Al-Qur'an adalah tebak ayat, sambung ayat, dan hafalan. Pada bagian menu utama juga terdapat judul game hafalan dan karakter anak muslim laki-laki. Ketika salah satu menu dipilih maka akan menuju ke antarmuka sesuai dengan pilihan. Activity diagram dan tampilan menu utama game dapat digambarkan seperti berikut:
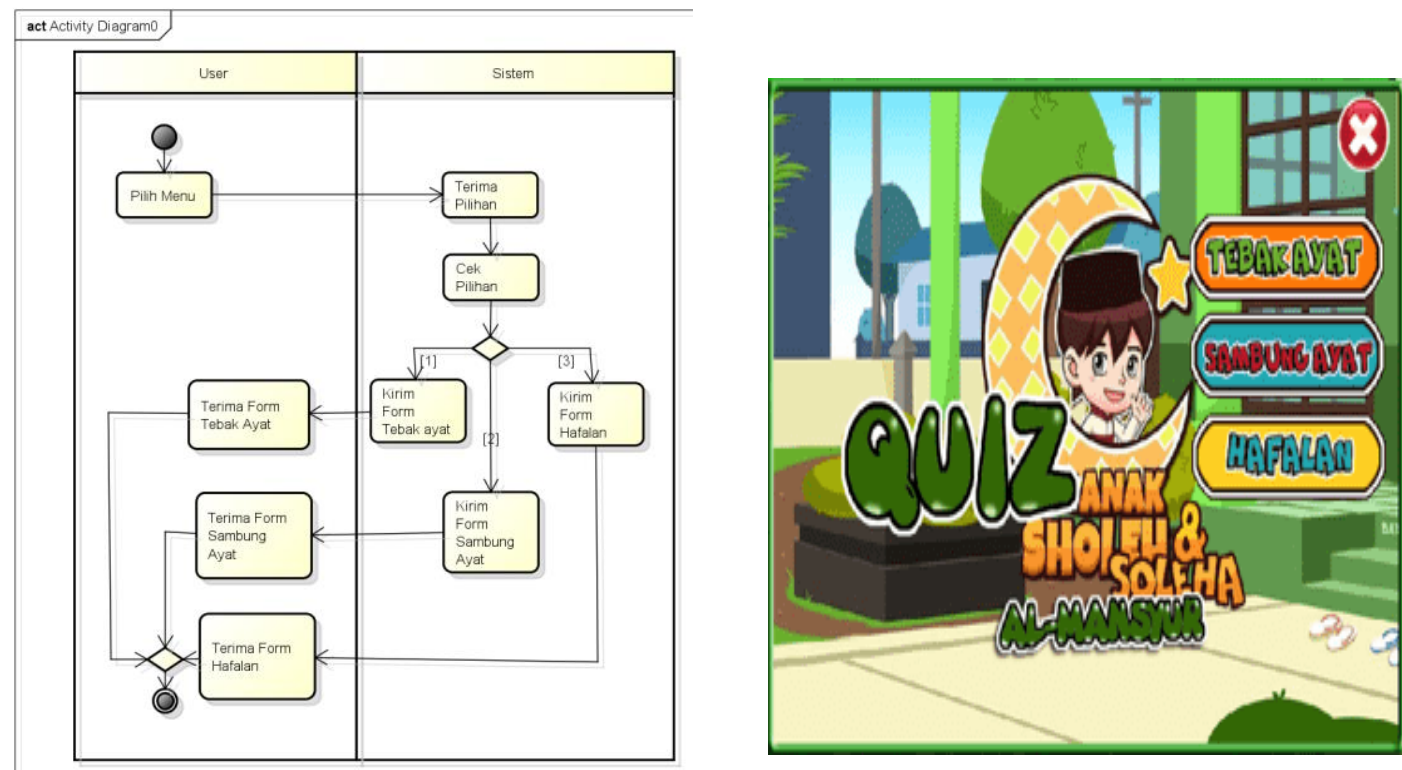

Gambar 3. Activity diagram tebak ayat \& tampilan depan. 


\subsection{Activity Diagram Tebak Ayat}

Hasil tampilan aplikasi antarmuka tebak ayat adalah tampilan untuk menebak ayat yang ditampilkan secara random/acak. Pada tampilan antarmuka tebak ayat, terdapat pilihan kelas dan semester. Siswa dapat memilih kelas dan semester yang sesuai. Jika telah dipilih maka klik tampilkan data. Ayat akan ditampilkan secara random dengan sound ayat yang sesuai dengan database. Selanjutnya, akan muncul 4 pilihan tebak ayat. Jika siswa ingin mendengarkan ayat lagi maka cukup klik tombol sound di sebelah tampilan ayat. Selanjutnya, siswa dapat memilih salah satu jawaban dengan mengarahkan kursor ke salah satu pilihan. Jika salah satu pilihan diklik maka akan tampil kotak konfirmasi pilihan jawaban. Siswa dapat memilih "YA" jika sudah yakin jawaban yang benar. Jika belum yakin tekan tombol "TIDAK" untuk mencari kembali jawaban yang benar. Jika jawaban yang dipilih benar maka sistem akan menginformasikan bahwa jawaban benar. Jika yang dipilih jawaban salah maka sistem akan menginformasikan jawaban salah dan akan menampilkan jawaban benar.

Activity diagram dan tampilan tebak ayat dapat digambarkan seperti berikut:
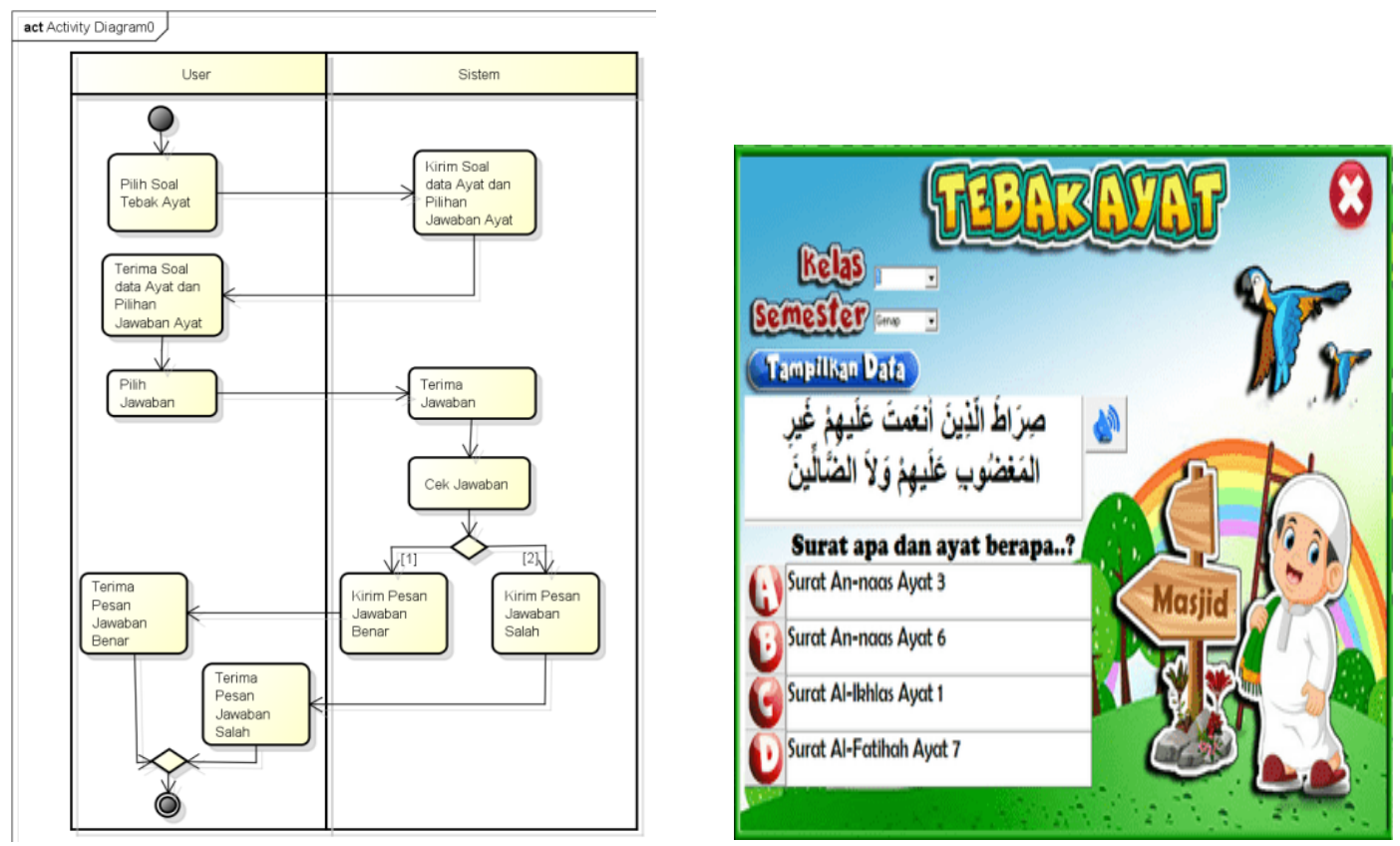

Gambar 4. Activity Diagram tebak ayat \& tampilan tebak ayat.

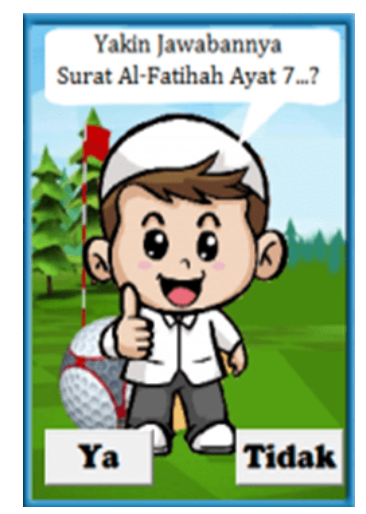

Gambar 5. Tampilan konfirmasi jawaban.

\subsection{Activity Diagram Sambung Ayat}

Hasil tampilan aplikasi antarmuka sambung ayat adalah tampilan antarmuka untuk memilih lanjutan ayat yang ditampilkan secara random/acak ayat. Pada antarmuka sambung ayat, terdapat pilihan kelas dan semester. Jika kelas dan semester telah terkonfirmasi oleh siswa (user), maka klik tampilkan data. 
Ayat dan sound ayat yang sesuai akan muncul dengan diikuti oleh 4 tampilan pilihan jawaban. Setiap pilihan jawaban akan menampilkan ayat dan di sebelahnya akan tampil tombol sound untuk mendengarkan suara pilihan ayat. Dengan demikian, pada antarmuka sambung ayat terdapat 5 ayat dan 5 tombol sound yang aktif yang dapat diklik oleh siswa.

Selanjutnya, jika telah yakin dengan pilihannya, maka siswa dapat mengeklik salah satu pilihan. Jika salah satu pilihan diklik maka akan tampil kotak konfirmasi pilihan jawaban. Siswa dapat memilih "YA" jika sudah yakin jawaban yang benar. Jika belum yakin tekan tombol "TIDAK" untuk mencari kembali jawaban yang benar. Siswa juga dapat mengeklik tombol-tombol (buttons) sound pilihan ayat untuk mendengarkan suara ayat. Jika jawaban yang dipilih benar maka sistem akan menginformasikan bahwa jawaban "BENAR". Jika yang dipilih jawaban salah maka sistem akan menginformasikan jawaban salah dan akan menampilkan jawaban benar.

Activity diagram dan tampilan sambung ayat dapat digambarkan seperti berikut:
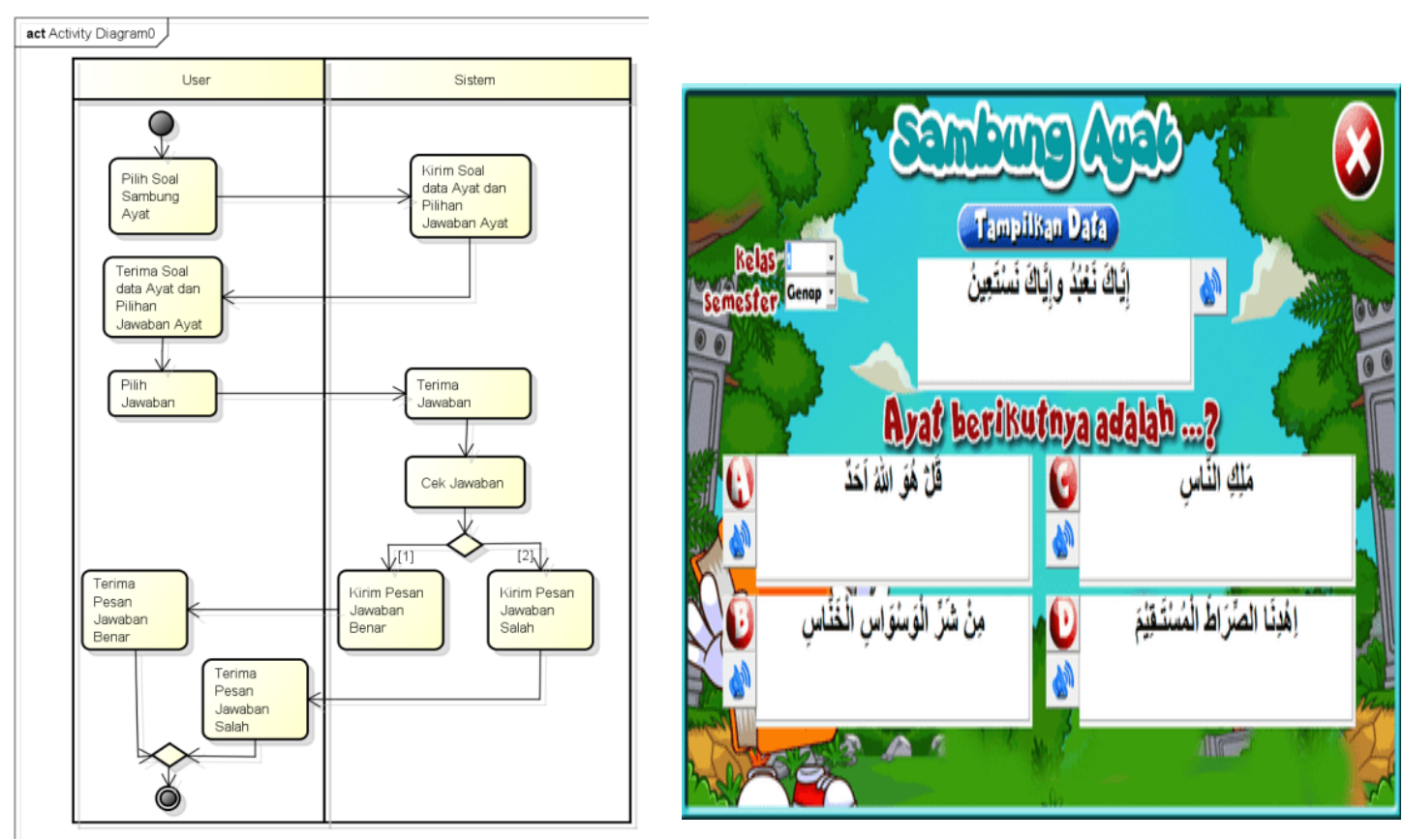

Gambar 6. Activity diagram sambung ayat \& tampilan sambung ayat.

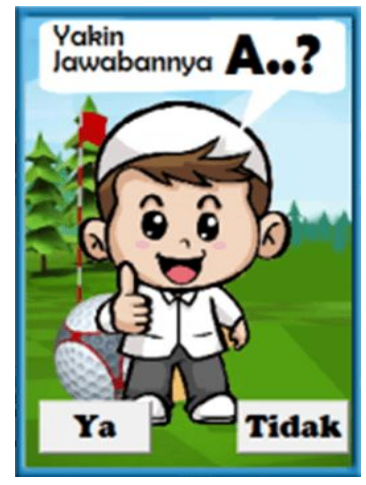

Gambar 7. Tampilan konfirmasi jawaban.

\subsection{Activity Diagram Hafalan Surat}

Hasil tampilan antarmuka yang terakhir adalah tampilan antarmuka hafalan surat. Menu ini berfungsi untuk hafalan surat bagi siswa. Pada antarmuka ini terdapat pilihan kelas, semester, kode surat, nama surat, dan jumlah ayat. Pilihan yang aktif dan dapat dipilih oleh user adalah kelas, semester, dan nama surat. Sedangkan pilihan kode surat dan jumlah ayat bersifat statis, berdasarkan input-an database. Jika kelas, semester, dan nama surat telah dipilih maka siswa dapat mengeklik mulai untuk memulai mendengarkan ayat dan membaca tampilan ayat. 
Activity diagram dan tampilan hafalan surat dapat digambarkan seperti berikut:
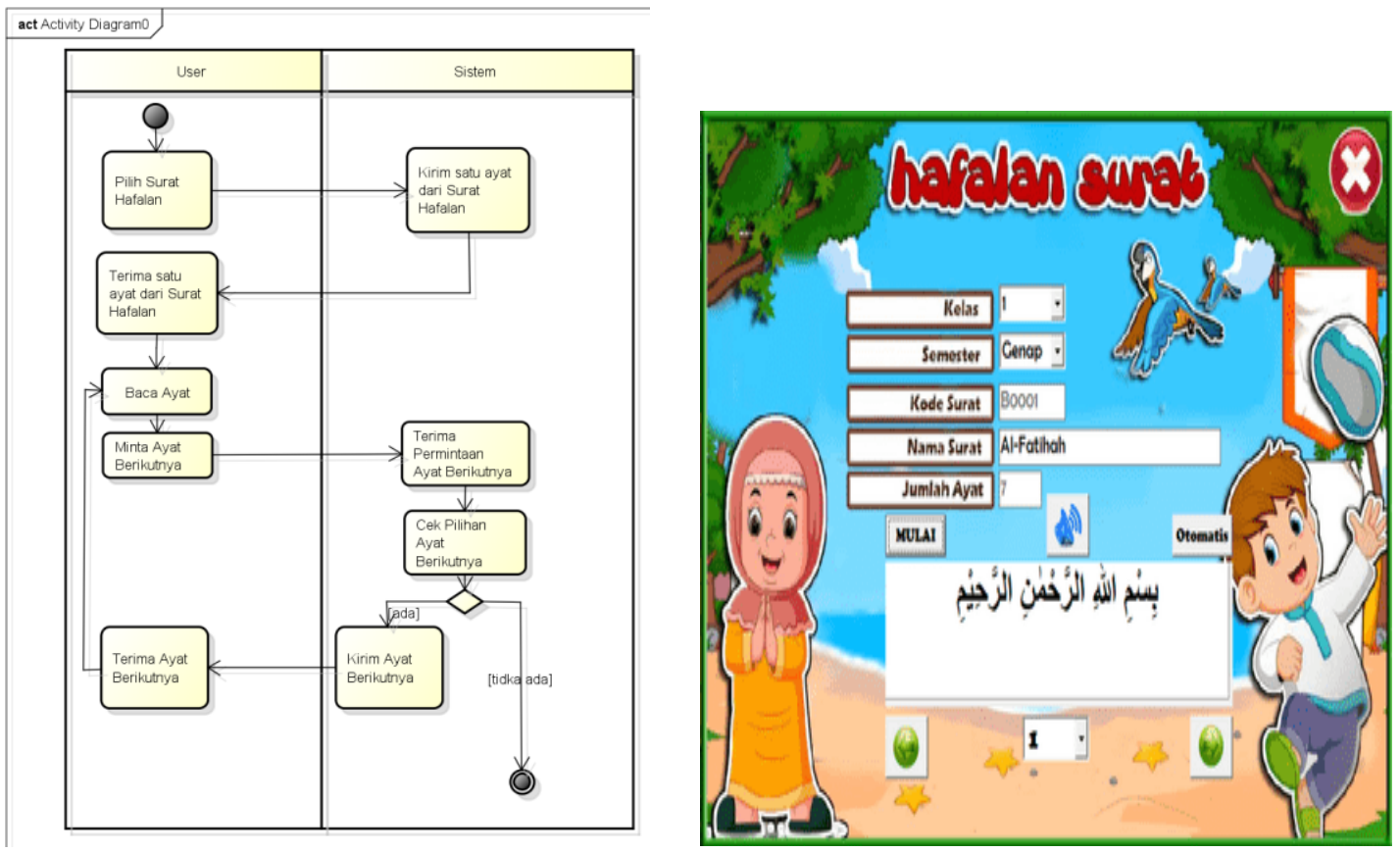

Gambar 8. Tampilan layar hafalan surat.

Secara default, aplikasi akan menampilkan ayat pertama dan sound ayat yang bersesuaian. Untuk melanjutkan atau mengulanginya, user dapat mengeklik button panah kiri atau kanan. User juga dapat memanfaatkan fasilitas button otomatis untuk mendengarkan ayat secara berkelanjutan. Selain itu siswa juga dapat memilih ayat yang ingin dimulai. Jika secara default, ayat yang ditampilkan adalah ayat pertama maka siswa dapat memilih ayat yang ingin pertama kali dibaca dan didengarkan. Fitur ini berfungsi untuk mempermudah hafalan siswa. Biasanya guru tidak memberikan tugas hafalan surat full satu surah tetapi membaginya menjadi beberapa ayat saja. Dengan adanya fitur ini maka siswa (user) dapat berkonsentrasi menghafal ayat-ayat yang ditugaskan saja.

\section{Kesimpulan}

Berikut ini kesimpulan yang dapat kami sampaikan setelah melaksanakan hasil penelitian ini, yaitu:

1. Game hafalan dirancang dan dibangun menggunakan metode Waterfall dan menggunakan Uniform Resource Locator (URL) untuk mengambil data suara ke Dropbox Service.

2. Game hafalan dibangun dengan fitur tampilan depan, tebak ayat, sambung ayat, dan hafalan surat dengan fitur tebak ayat dan sambung ayat dilengkapi oleh konfirmasi jawaban benar atau salah.

3. Fitur-fitur pada aplikasi dikategorikan pada kelas, semester, kode surat, nama surat, dan jumlah ayat, sehingga user (siswa) dapat menyesuaikan materi sesuai dengan kebutuhan hafalannya.

\section{Daftar Pustaka}

[1] N. Hidayah, R. Afwani, and A. H. Jatmika, "Rancang Bangun Aplikasi Bantu Hafal Al-Qur'an Metode At-Taisir Berbasis Android," J-Cosine, vol. 3, no. 1, pp. 30-38, 2019.

[2] V. Maarif, H. M. Nur, and W. Rahayu, "Aplikasi Pembelajaran Ilmu Tajwid Berbasis Android," Evolusi J. Sains dan Manaj., vol. 6, no. 1, pp. 91-100, 2018.

[3] F. Firdausi, "Optimasi Kecerdasan Majemuk Sebagai Metode Menghafal Al-Qur'an (Studi atas buku 'Metode Ilham: Menghafal al-Qur' an serasa Bermain Game' karya Lukman Hakim dan Ali Khosim)," J. Stud. Ilmu-Ilmu Al-Qur'an dan Hadis, vol. 18, no. 2, pp. 189-210, 2017.

[4] G. Schulz, Cloud and Virtual Data Storage Networking. New York: CRC Press Taylor \& Francis Group, 2011.

[5] R. S. Pressman, Software Engineering: A Practitioner's Approach, 7th ed. New York: McGraw-Hill Education, 2010. 